cational approach: they reach audiences around the world, provide the latest information, facilitate interaction, and meet some of the demand for continuing education credit for $\mathrm{HCWs}$.

\section{REFERENCES}

1. Canavan K. Nurses' CE options expand with distance learning. Am J Nurs 1997;97:59-60.

2. Masys DR. Advances in information technology. Implications for medical education. West J Med 1998;168:341-347.

3. Stinson ER, Mueller DA. Survey of health professionals' information habits and needs. JAMA 1980;243:140-143.

4. Davis DA, Thomson MA, Oxman AD, Haynes RB. Changing physician performance. A systematic review of the effect of continuing medical education strategies. JAMA 1995;274:700-705.

5. Dawes BS. Can distance learning provide a twenty-first century hallmark? AORN J 1998;68:170-172,174.

6. Hogg W. The computer, CME, and the family physician. CMAJ $1991 ; 144: 346-348,351$.

7. Lewis CE. Continuing medical education: past, present, future. West $J$ Med 1998;168:334-340.

8. Holsgrove G. Techniques for distance learning. Practitioner 1991;235: 296-300.

9. Skolnick AA, Shelton W. Experts explore emerging information technologies: effects on medicine. JAMA 1996;275:668-670.

10. Koop CE. Why CME? Presented at the Third International Conference on Continuing Medical Education, December 14, 1989. Connecticut Medicine 1991;55:218-221.

\title{
Outbreak of Clostridium perfringens Associated With Pureed Food
}

\author{
Gina Pugliese, RN, MS \\ Martin S. Favero, PhD
}

Tallis and coinvestigators from Melbourne, Australia, investigated the source of a nursing home outbreak of gastroenteritis in 1997. A retrospective cohort study was performed. Fecal and food samples and environmental swabs were assayed, and food- handling procedures reviewed. There were 25 cases, and 21 of these had their meals pureed (liquidized). The relative risk for eating pureed food and becoming ill was $5.8\left(\mathrm{CI}_{95}, 2.2-15.4\right)$. Clostridium perfringens and its enterotoxin were detected in nine fecal samples. Samples of pureed food tested positive for coliform bacteria.

Food liquidizing provides opportunities for recontamination of cooked food through the use of contaminated equipment and deficiencies in foodhandling practices. Pureed foods should be reheated to $70^{\circ} \mathrm{C}$ after liquidizing to inactivate pathogens.

FROM: Tallis $\mathrm{G}, \mathrm{Ng} \mathrm{S}$, Ferreira C, Tan A, Griffith J. A nursing home outbreak of Clostridium perfringens associated with pureed food. Aust $N Z$ J Public Health 1999;23:421-423.

\section{Use of Avoparcin as a Growth Promoter and the Occurrence of VRE in Norwegian Poultry and Swine}

Kruse and colleagues from the Norwegian School of Veterinary Science, Oslo, Norway, have conducted a study that documents a strong and statistically significant association between the use of the glycopeptide avoparcin as a growth promoter in Norwegian poultry production and the occurrence of vancomycin-resistant Enterococcus species (VRE). Avoparcin was approved as a feed additive for broilers and turkeys in Norway in 1986 and was banned on June 1, 1995. In a survey conducted in Norway between June 1995 and March 1997, VRE were isolated from fecal samples from 106 of 109 poultry houses previously exposed to avoparcin (97\%) and from 6 of 33 poultry houses never exposed to avoparcin (18\%; RR=5.35). Samples from previously exposed poultry houses were collected in three time periods. The proportion of positive samples remained high (96\%-98\%) in all three time periods indicating a persistence of vancomycin resistance among enterococci for more than a year and a half after the withdrawal of avoparcin.

VRE also were isolated from 6 of 10 poultry farmers living on farms previously exposed to avoparcin and from none of 16 farmers living on farms never exposed to avoparcin. Moreover, VRE were isolated from 68 of the 225 broiler carcasses investigated $(30 \%)$. The resistance to vancomycin was a high-level type $(\mathrm{MIC} \geqslant 256 \mu \mathrm{g} / \mathrm{mL}$ ) mediated by the vanA gene. For comparison, VRE could only be isolated from 2 of 147 fecal samples from Norwegian groups of swine (1\%). Because avoparcin never has been used in Norwegian swine production, this observation strengthens the association between the use of avoparcin in animal husbandry and the occurrence of VRE.

FROM: Kruse H, Johansen BK, Rorvik LM, Schaller G. The use of avoparcin as a growth promoter and the occurrence of vancomycinresistant Enterococcus species in Norwegian poultry and swine production. Microb Drug Resist 1999;5:135-139. 